\title{
Towards a Framework for Evaluating Quality Teaching in Higher Education
}

\author{
Maoto Rose Satsope \\ Department of Mathematics, Science and Technology Education, University of Limpopo \\ Email: satsope.maoto@ul.ac.za \\ Masha Kwena John \\ Department of Mathematics, Science and Technology Education, University of Limpopo \\ Email: kwena.masha@ul.ac.za \\ Chuene Kabelo \\ Department of Mathematics, Science and Technology Education, University of Limpopo \\ Email: kabelo.chuene@ul.ac.za \\ Themane Mahlapahlapana \\ Department of Education Studies, University of Limpopo \\ Email:mahlapahlapana.themane@ul.ac.za
}

Doi:10.5901/mjss.2015.v6n4s1p223

\section{Abstract}

The three main functions in Higher Education (HE) are teaching, research and community engagement (Vardi and Quin 2011). These three are equally important. However, recognition of teaching and community engagement currently seem to enjoy less prominence than research. This may be due to a lack of a proper framework in evaluating the other two. The aim of this article is to initiate a discourse on the development of a framework teaching evaluation in HE. We present: 1) a rationale for the development of a framework for the evaluation of teaching in higher education; 2) a design for a framework for evaluating teaching and 3) an exemplar for such a framework.

Keywords: higher education, teaching, evaluation framework, exemplar

\section{Introduction}

The main functions in Higher Education (HE) are teaching, research and community engagement (Vardi and Quin 2011). These three are equally important. However, recognition of teaching and community engagement currently seem to enjoy less prominence than research (Garbett 2013). In the last ten years there has been a renewed interest in the intrinsic value of teaching in Higher Education (HE) (Goldstein, Gary and Victor 2006; Harrison, Douglas and Burdsal 2006). This interest has stimulated debates about the place of teaching in HE. Traditionally, teaching has been accepted by university academic staff as less important (Boyer 1990; Webbstock, 1999). As a result of this there has been a tendency to subordinate it to research (Vardi and Quin 2011). However, with the shift of focus to students' throughputs and the need for public accountability on how funds are used, more and more attention is being given to the value of teaching (Kwiek 2012; Cochran-Smith 2003; Hazelkorn 2013). Despite this change of focus on the value of teaching, there appears to be no discourse on the criteria to be used to judge quality teaching, both within and across universities, at least in South Africa. Academic staff appear to react with scepticism, mistrust and anxiety when their teaching competencies are based exclusively on ratings of their classroom actions or certain technical skills, whether by their students or by their peers (Stes, De Maeyer, Gijbels and Van Petegem 2012). It is this reaction that has motivated us to propose a discourse on the development of an evaluation of quality teaching framework. We have designed this article as follows: first, we look at the rationale for the development of a framework for an evaluation of quality teaching. Second, we propose the design such a framework should follow. Third, we set out an exemplar for such a framework. 


\section{Rationale for a Framework for Evaluating Quality Teaching}

In South Africa, and probably elsewhere in the developing countries, the current experience is that institutions have crafted themselves individualised approaches to recognising excellence in teaching (Boshier 2009). Unlike with research, where there is fairly a common and an established mechanism for rewarding excellence, there is no common ground with regard to the evaluation of teaching (Vardi and Quin 2011). Research has established bodies like the National Research Fund (NRF) which among other things sets standards upon which quality research is established and can be benchmarked (Hardland, Hussain and Bakar 2013). This type of arrangement seems to be lacking in the evaluation of quality teaching. This lack of commonly agreed criteria to assess equality teaching raises issues of credibility if it is to be compared to research and its portability remains largely unknown whenever teaching is to be evaluated.

As indicated earlier, the growing concern over demonstrating public accountability on how funds are spent (Boshier 2009) which is normally measured through student success, has led to increased focus towards assessing the value of teaching in HE, especially at the undergraduate level (Blackburn, and Lawrence. 1995). Quality teaching to ensure student success is therefore no longer an option but a must. Also, there is a growing realisation of the need to recognise teaching as a scholarly activity and therefore an alternative route to staff promotion (Webbstock 1999; Curtin University of Technology 2009). If this route is to gain any credence there is a need for a framework on the evaluation of what quality teaching entails. Pursuance of this route is already established elsewhere (Blackburn and Lawrence 1995; Biggs 2003). Where this route is still resisted could be as a result of an agreed upon framework for the evaluation of quality teaching. These and other reasons have persuaded us to initiate a discourse on a possible framework for the evaluation of quality teaching. We argue that there is a need to develop a framework to guide universities to evaluate what quality teaching entails.

\section{Teaching Evaluation Framework in the South African Setting}

In this section, we focus on the proposed development of a teaching evaluation framework for higher education institutions within a South African setting. First, we provide a snapshot of the complexity of teaching and thus demonstrate the need for a framework that is largely flexible. Secondly, we present the model itself and to provide details of its components.

\subsection{Complexity of teaching in higher education}

Teaching is a complex activity influenced by many factors (Cochran-Smith 2003). Its complexity is reflected by among others things a myriad literature, diverse nature of disciplines (subjects), physical and psychosocial learning environments, students' backgrounds. Primarily different philosophical positions have their own views on what constitutes quality-teaching outcomes (Garbett 2013). Thus, criterion developed in one paradigm is not necessarily applicable in another. The challenge, therefore, is to come up with a framework that should be sensitive to these diverse views.

The nature of a discipline places different demands on teaching and learning skills, hence differentiated performance levels by students with different aptitudes. Language learning, for example, demands certain skills like extensive reading and writing skills different from those required for mathematics learning (Truong 2013) Teaching and learning evaluation embedded in subject content contexts should be flexible enough to cater for the differences in other situations whilst still coherent enough to reflect a common framework.

Teaching staff within and across institutions experience imbalances in the distribution of learning spaces and resources. This distribution depends on geographical location of their institutions (Cochran-Smith 2003), the socioeconomic factors around an institution (Garbett 2013) and the students it attracts, etcetera (Hardland, Hussain and Bakar 2013). Thus, it will be unjust to subject teaching staff to research ability without considering other activities like teaching that are part of academics. In addition, one need to consider diverse qualities of institutions: their challenges and their strong focus when dealing with challenges. Therefore, there is a need for a versatile evaluation framework that may accommodate these diversities.

Teaching has both short term and long-term impact on students' learning. What students learn from interaction with one lecturer might benefit interactions with the other (Komarraju, Sergey and Gargi 2010). For instance, attitudes that emanate from experiences in one encounter continue to affect how students engage in subsequent encounters such how to react to questions, when to keep silent and how to participate in discussions. All these make it a challenge to evaluate an individual staff's impact on teaching. 
In the midst of these diverse contexts, it becomes a challenge to pin down neutral criteria, which is not dogmatic, for the evaluation of teaching. However, our contention is that all teaching, regardless of their complexities and diversities, considers three factors: inputs, processes and outputs. It is against this backdrop that we propose a teaching evaluation framework (TEF) that takes into account of these factors. In turn, these factors derive from three areas: national and institutional policies; the nature of the discipline taught; and the students' socio-economic and cultural backgrounds. These areas are illustrated in Figure 1 hereunder.

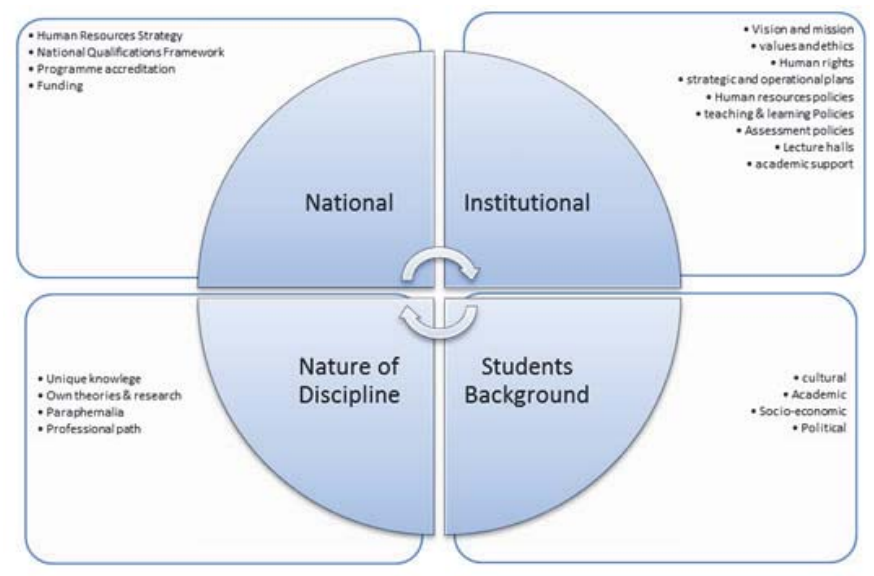

Figure 1. Illustrating the four factors

Source: Designed by Kwena Masha

The three factors have specific areas that define them as shown in table 1

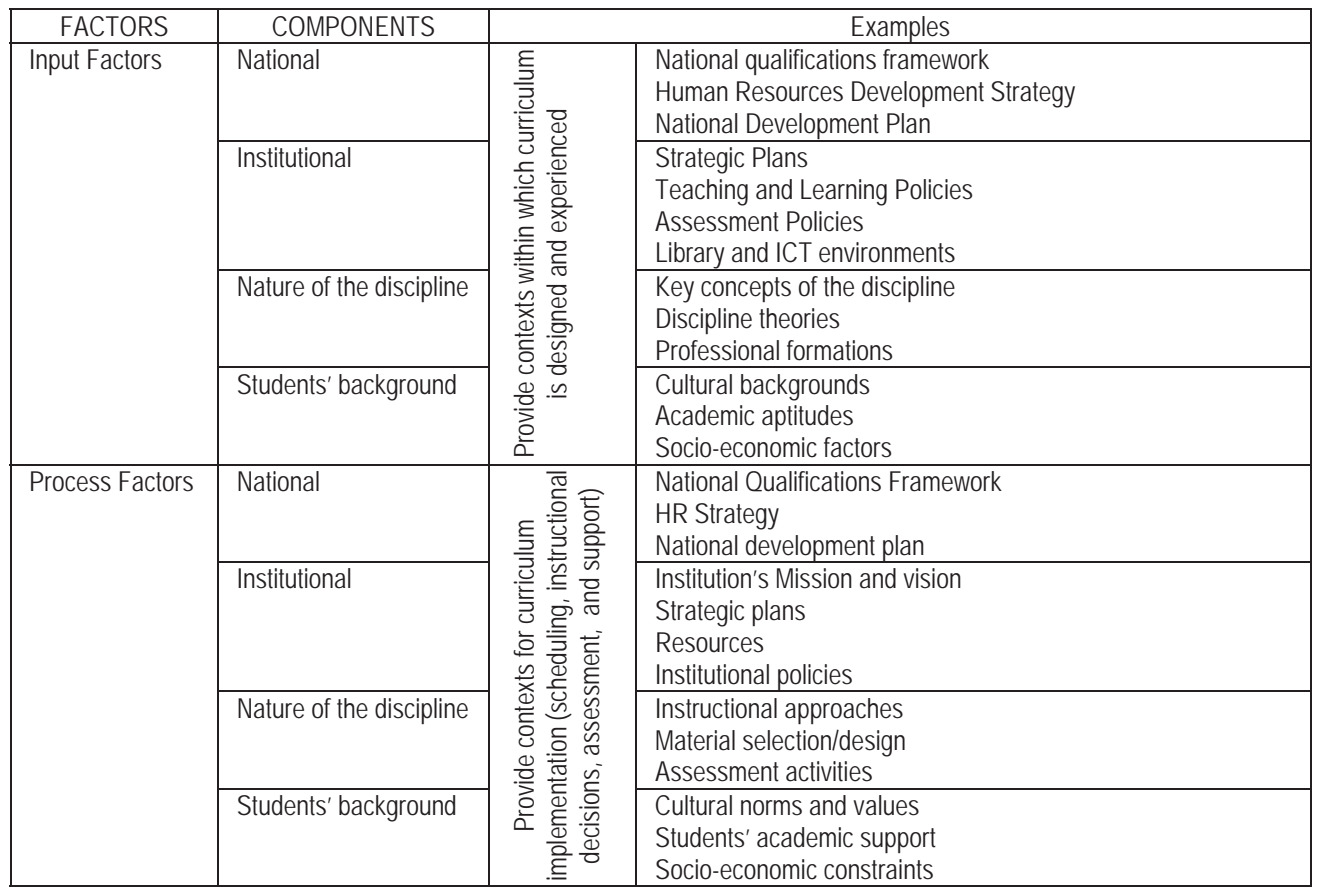




\begin{tabular}{|c|c|c|c|}
\hline \multirow[t]{4}{*}{ Output Factors } & National & \multirow{4}{*}{ 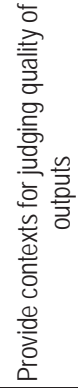 } & $\begin{array}{c}\text { National Qualifications Framework (level descriptors) } \\
\text { Human Resource Development (Employability of Graduates) } \\
\text { National Development Plan }\end{array}$ \\
\hline & Institutional & & $\begin{array}{l}\text { Student retention and throughput rates Module/programme } \\
\text { impact (acknowledgements) } \\
\text { Graduate attributes in relation to institution's strategic plans } \\
\text { and identity }\end{array}$ \\
\hline & Nature of the discipline & & $\begin{array}{l}\text { Students discipline knowledge levels } \\
\text { Progression within the discipline } \\
\text { Contribution to professional activities }\end{array}$ \\
\hline & Students' background & & $\begin{array}{c}\text { Enhanced students' experiences } \\
\text { Adding value to students communities }\end{array}$ \\
\hline
\end{tabular}

\subsection{Input factors}

Input factors relate to all areas and systems that characterise the context within which teaching takes place. Some of these factors emanate from national in the form of legislation, policies, funding frameworks, and other directives from national bodies such as Council for Higher Education. We argue that there is a need for standardisation and accountability warrants that Higher Education institutions in the country operate from shared frameworks.

At institutional level, input factors come in the form of policies, strategic plans, resource allocations, learning spaces, and all other issues that contribute to staff and students' overall academic wellbeing (Boshier 2009). Staff offices and students' accommodation for example, have impact on their academic work. The value that an institution places on teaching, reward systems, development support mechanisms and monitoring plans have influences on the efforts that teaching staff places on improving their teaching (Vardi and Quin 2011).

The nature of the discipline also contributes to input factors. Other disciplines require practical work as a major component of teaching, other require work integrated learning whilst others can do without these components. Different disciplines have different concepts, methodologies and theories that place different requirements on teaching and learning (Truong 2013). Professional bodies such as Pharmaceutical Board, Social Work too, have direct influences on what to teach in a discipline (Ceulemans, Maartrn and Struyf 2012). In many instances, an individual lecturer does not have control over these areas. Some of these, mentioned earlier, include the national legislation; Institutional policy environment; the nature of the discipline and the students' socio-economic background as shown in table 1.

\subsection{Process factors}

Competence in the teaching process requires provision of comprehensive evidence of teaching activities and accomplishments (Seeleman, Suurmond and Stronks 2009). Provision of evidence developed to make conclusions about one's own teaching requires a careful study of the unique elements of one is teaching roles. For example, one has to consider the size and the level of modules (Ceulemans, Maartrn and Struyf 2012): outcomes content and the learning environment (Truong 2013) One needs to consider the philosophy (Truong 2013) that underpins one's efforts to help students learn and plan (Ceulemans, Maartrn and Struyf 2012), facilitate learning and assess the students (Ceulemans, Maartrn and Struyf 2012). In addition, one must provide evidence to show that the module outcomes have been met and demonstrate one's involvement in all teaching-related activities, including curricula revision and teaching evaluation. All these aspects collectively constitute the process factor

The components in TEF are not mutually exclusive entities; they are nested circles to provide a backdrop for each other. All of them provide shape, character, breadth, depth and attitude against which teaching evaluation judgements could be made in the proposed framework. The shape, nature and depth of teaching which will allow one to identify it

\section{Exemplar}

Input factors are beyond a lecturer's control, but affect the quality of teaching as they dictate context in which teaching occurs (Garbett 2013). Currently providing access and success to candidates in science related programmes is encouraged (Ceulemans, Maartrn and Struyf 2012). This legislated need if drafted into institutional policy may result in overcrowded classrooms. Suggestions for teaching in overcrowded classrooms require state of the art technology for it to be efficient (Vardi and Quin 2011). While some universities enjoy such luxuries, environments throttle other (Garbett 2013). In such instances, quality teaching should consider these. A score of $50 \%$ in one institution may mean different 
value and that interpretations are dictated to by different contexts. For example, in institutions where academic support offices are present and functional, students support is dealt with at that level and students achieve deeper insights in the content base of study. In institutions where academic support is invisible, the responsibility of dealing with students at risk is left to the lecturer and students achieve less in terms of content base. Evaluation of quality teaching may, thus, be compromised in the latter and consequently quality may be overshadowed by the need for compliance.

\subsection{Output factors}

The ultimate goal of teaching is the success of student learning (Gibbs and Tang 2011). Every form of teaching is characterised by the roles the teachers play in order for the students to succeed (Gibbs and Coffey 2004). Thus, all good teaching should seek to inspire students to reach their full potential (Vardi and Quin 2011). At the university, the effect will be measurable through output factors and these will range from students' results (Vardi and Quin 2011). To how students fit into the real world of work. They may include student results, examiners' reports, students' attrition and completion rates and graduate destinations (Boshier 2009). These and other output factors are influenced by national legislation; institutional policies; the nature of the discipline and students' backgrounds

\section{Conclusion}

With teaching becoming more and more important in the agenda of $\mathrm{HE}$, there is need for clarity as to how it is to be evaluated. It needs to be carefully conceived and represented if it is to acquire the same value and effort in promoting scholarship in a university. In this paper, we have argued for a discourse if that is to happen. We have presented framework that can be used for that purpose. More work is invated to engage our framework.

\section{References}

Andresen, L.W. 2000. A useable, trans-disciplinary conception of scholarship. Higher Education Research and Development 19(2): 137153.

Barrow, M and B Grant. 2012. The 'truth' of academic development: how did it get to be about 'teaching and learning'? Higher Education Research \& Development, 31_(4): 465-477.

Beehr, T. A. and T.D. Taber. 1993. Perceived intra-organisational mobility: reliable versus exceptional performance as means to getting ahead. Journal of Organisational Behaviour 14(6): 579-594.

Biggs, J. 2003. Teaching for quality learning at university: What the student does. $2^{\text {nd }}$ ed. Buckingham: Society for Research into Higher Education/Open University Press.

Blackburn, R.T. and J.H. Lawrence. 1995. Faculty at work. Motivation, expectation, satisfaction. Baltimore: John Hopkins University Press.

Boshier, R. 2009. Why is the scholarship of teaching and learning such a hard sell? Higher Education Research and Development 28(1): 1-15.

Boyer, E. L. 1990. Scholarship reconsidered: Priorities of the professoriate. New Jersey: Princeton University Press.

Boyer, E. L. 1997. Scholarship reconsidered: Priorities of the professoriate. Jossey-Bass: The Carnegie Foundation for the Advancement of Teaching.

Breier, M. and M. Mabizela. 2008. Higher education. In Human resources development review 2008: Education, employment and skills in South Africa, ed. A. Kraak and K. Press, 278-299. Cape Town: Human Science Research Council Press.

Carr, R., Y. Fung and S. K. Chan. 2002. Distance education for teacher education: Hong Kong experience. Journal of In-service Education 28(1): 163-178.

Ceulemans, C, Maarten S, and S Elke S 2012. Professional standards for teachers: how do they 'work'? An experiment in tracing standardisation in-the-making in teacher education." Pedagogy, Culture \& Society, 20(1): 29-47.

Cochran-Smith, M. 2003. The unforgiving complexity of teaching: Avoiding simplicity in the age of accountability. Journal of Teacher Education, 54(1): 3-5.

Crosling, G., M. Heagney and L. Thomas. 2009. Improving student retention in higher education. Australian Universities Review 51(2): 9 18.

Curtin University of Technology. 2009. Guidelines for applicants' academic promotion to levels C, D and E. http://hr.curtin.edu.au/files/ career_dev/academic_promotions/2010R1_Guidelines_C_D_E_FINAL_161209. doc (accessed February 16, 2009).

du Toit, D. 2011. Conceptualising the re-design of the curriculum for teacher education. Acta Academia 43(3): 107-131.

Gibbons, M., C. Limoges, H. Nowotny, S. Schwartzman, P. Scott and M. Trow. 1994. The new production of knowledge: The dynamics of science and research in contemporary societies. London: SAGE Publications Ltd.

Garbett, D 2013. Promotion by teaching distinction: Developing resilience and cache for a track less travelled. Studying teacher education: A journal of self-study of teacher education practices, 9 (2): 108-117. 
Gibbs, G. and M. Coffey. 2006. The impact of training of university teachers on their teaching skills, their approach to teaching and the approach to learning of their students. Active Learning in Higher Education 5(1): 87-100.

Gibbs, J. and C. Tang. 2011. Teaching for quality learning at university. London: Open University Press.

Goldstein, G.S, and Benassi, V.A. 2006. Students' and instructors' beliefs about excellent lecturers and discussion leaders. Research in Higher Education 47(6):685-707.

Gould, S. and L. E. Penely. 1984. Career strategies and salary progression: A study of their relationships in a municipal bureaucracy. Organisational Behaviour and Human Performance 34(2): 244-265.

Gulikers, J., T. Bastiaens and P. Kirschner. 2004. A five-dimensional framework for authentic assessment. Educational Technology Research and Development 52 (3): 67-85.

Handel, S. J. and A. Herrera. 2003. Access and retention of students from educationally disadvantaged backgrounds: Insights from the University of California. In Improving completion rates among disadvantaged students, ed. E.Thomas, M. Cooper and J. Quinn, 33-52. London: Trentham Books Limited.

Harland, T., Hussain, R. M. R. and A.A Bakar 2013. The scholarship of teaching and learning: challenges for Malaysian academics. Teaching in Higher Education. London: Rutledge group

Harrison, P.D. Douglas, D.K. and Burdsal, A.A. 2004. The relative merits of different types of overall evaluations of teaching effectiveness. Research in Higher Education 45(3):311-323.

Hay, H. R. and M. E. Herselman. 2001. An investigation into the perceptions of academic staff on quality assurance in teaching and learning at selected South African universities. South African Journal of Higher Education 15(3): 131-141.

Hazelkorn, E. 2013. How Rankings are reshaping Higher Education in Climent, V., Michavila, F. and Ripolles, M. (eds): Los Rankings Univeritarios: Mitos Realidades, Ed. Tecnos.

Jarvey, P. and A. Usher. 2012. Measuring academic research in Canada: Field-normalized academic. http://higheredstrategy.com/wpcontent/uploads/2012/ 08/rankings2012.pdf. (accessed February 27, 2013).

Komarraju, M, Sergey, M, and B. Gargi. 2010. Role of Student-Faculty Interactions in Developing College Students' Academic SelfConcept, Motivation, and Achievement." Journal of College Student Development, 51 (3): 332-342.

Kreber, C. 2005. Charting a critical course on scholarship of university teaching movement. Studies in Higher Education 30(4): $389-405$.

Kreber, C. and P. Cranton. 2000. Exploring the scholarship of teaching. Journal of Higher Education 71(4): 476-495.

Kuh, G. D., J. Kinze, J. H. Shuh and E. J. Whitt. 2005. Student success in college: Creating conditions that matter. San Francisco: Jossey-Bass.

Ladson-Billings, G. 1995. But that's just good teaching! The case for culturally relevant pedagogy. Theory into Practice 34(3): 159-165.

Macdonald, C. A. 1990. Ballpoint pens and braided hair: An analysis of reasoning skills and the curriculum. Pretoria: Human Sciences Research Council.

Mueller, J. 2006. Authentic assessment toolbox. http://jonathan.mueller.faculty noctrl.edu/toolbox/whatisit.htm\#looklike (Accessed June $30,2006)$.

Oliver, B., S. Jones, B. Tucker and S. Ferns. 2007. Mapping curricula: Ensuring work-ready graduates by mapping course learning outcomes and higher order thinking skills. Peer-reviewed paper presented the Evaluations and Assessment Conference, Brisbane. http://www. eac2007.qut.edu.au/ proceedings/proceedings ebook.pdf. (Accessed August 24, 2008).

Ostrander, S. A. 2004. Democracy, civic participation and the university: A comparative study of civic engagement on five campuses. Non-Profit and Voluntary Sector Quarterly 33(1): 73-94.

Prosser, M. 2008. The scholarship of teaching and learning: What is it? A personal view. International Journal for the Scholarship of Teaching and Learning 2(2): 1-4.

Readings, B. 1996. The university in ruins. Cambridge: Harvard University Press.

Seeleman, C, Suurmond, J, and K Stronks 2009. Cultural competence: a conceptual framework for teaching and learning." Medical Education, 43 (3): 229-237.

Sjoberg, S. 2010. Constructivism and learning. In International Encyclopaedia of Education $3^{\text {rd }}$ Edition, ed. E. Baker, B. McGaw and P. Peterson, 485-490. Oxford: Elsevier.

Stes, A., De Maeyer, S., Gijbels, D. and P Van Petegem. 2012. "Instructional development for teachers in higher education: Effects on students' perceptions of the teaching-learning environment." British Journal of Educational Psychology 82, (3): 398-419.

Strydom, J. F., N. Basson and M. Mentz. 2012. Enhancing the quality of teaching and learning: Using student engagement data to establish a culture of evidence. Pretoria: Council on Higher Education.

Stuart, J. 1999. How research into programme for initial preparation of teachers can help improve the quality in teachers' colleges and schools. In Issues in Education: An occasional publication, B. Otaala, L. Mostert and C. Keyter. Namibia: University of Namibia and the National Institute for Education Development.

Sweller, J., P. A. Kirschner and R.E. Clark. 2006. Why minimal guidance during instruction does not work: An analysis of the failure of constructivist, discovery, problem-based, experiential, and inquiry-based teaching. Educational Psychologist 41(2): 75-86.

Themane, M. J. 2011. Understanding curriculum: A challenge to curriculum development in teacher education programmes. South African Journal of Higher Education 25(8): 1639-1651.

Tinto, V. 2003. Establishing conditions for student success. In Improving completion rates among disadvantaged students, ed. E. Thomas, M. Cooper and J. Quinn, 1-10. Oakhill: Trentham Books Limited.

Truong, N. 2013. Language of Instruction: Unlocking Effectiveness of Education and Sustainable Development in Sub-Saharan Africa." International Education 42 (1): 1-10. 
Uzoka, F.M. E. and O. A. Akinyoka. 2005. Factor analytic model for evaluating the effects of HR profile on organization productivity: A case study of university academic staff. South African Journal of Higher Education 19(3): 119-130.

Vardi, I. and R. Quin. 2011. Promotion and the scholarship of teaching and learning. Higher Education Research and Development 30(1): 39-49.

Vardi, Y. 1980. Organisational career mobility: An integrative model. Academy of Management Review 5(3): 341-355.

Volet, S. E. and G. Ang. 1998. Culturally mixed groups on international campuses: An opportunity for inter-cultural learning. Higher Education Research and Development 17(1): 5-25.

Vygotsky, L.S. 1981. The genesis of higher mental functions. In The concept of activity in Soviet psychology, ed. J.V. Wertsch, 37-53. Armonk, N.Y.: Sharpe.

Watkins, D., B. Dahlin and M. Ekholm. 2005. Awareness of the backwash effect of assessment: A phenomenographic study of the views of Hong Kong and Swedish lecturers. Instructional Science 33(4): 283-309.

Webbstock, D. 1999. An evaluative look at the model used in assessment of teaching quality at the University of Natal, South Africa: reflections, rewards and reconsiderations. Assessment \& Evaluation in Higher Education 24 (2): 157-179.

Yapa, L. 2006. Public scholarship in the postmodern university. In New Directions for Teaching and Learning, Spring (105): 73-83. Wiley InterScience.

Zha, Q. 2009. Diversification or homogenization: How governments and markets have combined to (re)shape Chinese higher education in its recent massification process. Higher Education 58(1): $41-58$.

Zhang, J. 2010. Amalgamation, expansion, quality assurance and innovations: A case study on a key university in China. PhD. thesis, Arizona State University.

Zhang, J. 2013. Promotion criteria, faculty experiences and perceptions: A qualitative study at a key university in China. International Journal of Educational Development 33(2): 185-195. 